\title{
What Is It Like to Be a Special Librarian at the Center for Creative Leadership?
}

\author{
by Carol Avis Keck
}

I f you work in a public, school, or academic library, you may occasionally wonder what it's like to be a special librarian. Having worked in a special library for 19 years, I was delighted to be asked to answer this question and to tell you a little about the Center for Creative Leadership (CCL).

\section{Definitions}

Special library is a category given to libraries in companies, nonprofits, newspapers, hospitals, law firms, associations, museums, and the like. Many special librarians say that the only thing special libraries have in common with each other is that we don't have anything in common. Our collections and services, even our patrons, vary greatly from library to library. Our collections and audiences tend to be more specialized than those of a public or academic library. At the CCL, for example, the collection focuses on leadership theory and research, industrial/organizational psychology, human resources management, and adult education. We exist primarily to serve the CCL staff, but participants in our educational programs may use our materials while they are at the Greensboro headquarters for a program. To paraphrase Elin Christianson, special libraries are distinguished from other libraries 1) by their emphasis on the information function; 2) by where they are found; 3 ) by the kinds or groups of people who use them or are served by them; 4) by limitations in subject scope; 5) by a predominant characteristic of "smallness"; and 6) by the presence of a professional librarian. ${ }^{1}$

The Center for Creative Leadership is a nonprofit, educational institution with a worldwide reach. For more than three decades, the CCL's mission has been to advance the understanding, practice, and development of leadership for the benefit of society worldwide. CCL staff members conduct research, produce publications, and provide programs, products, and educational experiences for leaders and organizations in all sectors of society. CCL research, for example, was instrumental in developing leadership theory about characteristics that support or derail individual careers. The Lessons of Experience: How Successful Executives Develop on the Job and many other publications and components of our programs and products have built a foundation for understanding leadership. Breaking the Glass Ceiling: Can Women Reach the Top of America's Largest Corporations? was instrumental in developing the knowledge base for women leaders. Research for the project led to the CCL's Women's Leadership Program and further research projects. Standing at the Crossroads: Next Steps for High-achieving Women represents the latest in this line of research. ${ }^{2}$ 
The CCL's educational programs are intensive, highly realistic learning experiences. They focus on facilitating the participant's self-awareness; improving his/her ability to relate to others; and integrating approaches to work, family, and community. Based on assessment, challenge, and support (a model that our research has shown to produce desirable change), participants receive a confidential wealth of information that can help them improve their leadership skills in an interactive setting. Our models of practice, such as the assessment, challenge, and support model, are summarized in The Center for Creative Leadership Handbook of Leadership Development. ${ }^{3}$ Since its establishment in 1970, the CCL has grown to include educational campuses in the United States in Colorado Springs and San Diego, and campuses abroad in Brussels and Singapore. The CCL also has licensed associates around the world approved to offer selected programs.

\section{History of CCL's Special Library}

The founders of the Center for Creative Leadership knew that if it was to be an educational and research institution, it would need a library. They hired a professional librarian before the CCL was even built or named. Frank Freeman and a handful of other staff worked downtown in the Greensboro offices of the Richardson Foundation. Being able to shape the library and the collection from the very beginning, he used technology to organize and share the library's growing

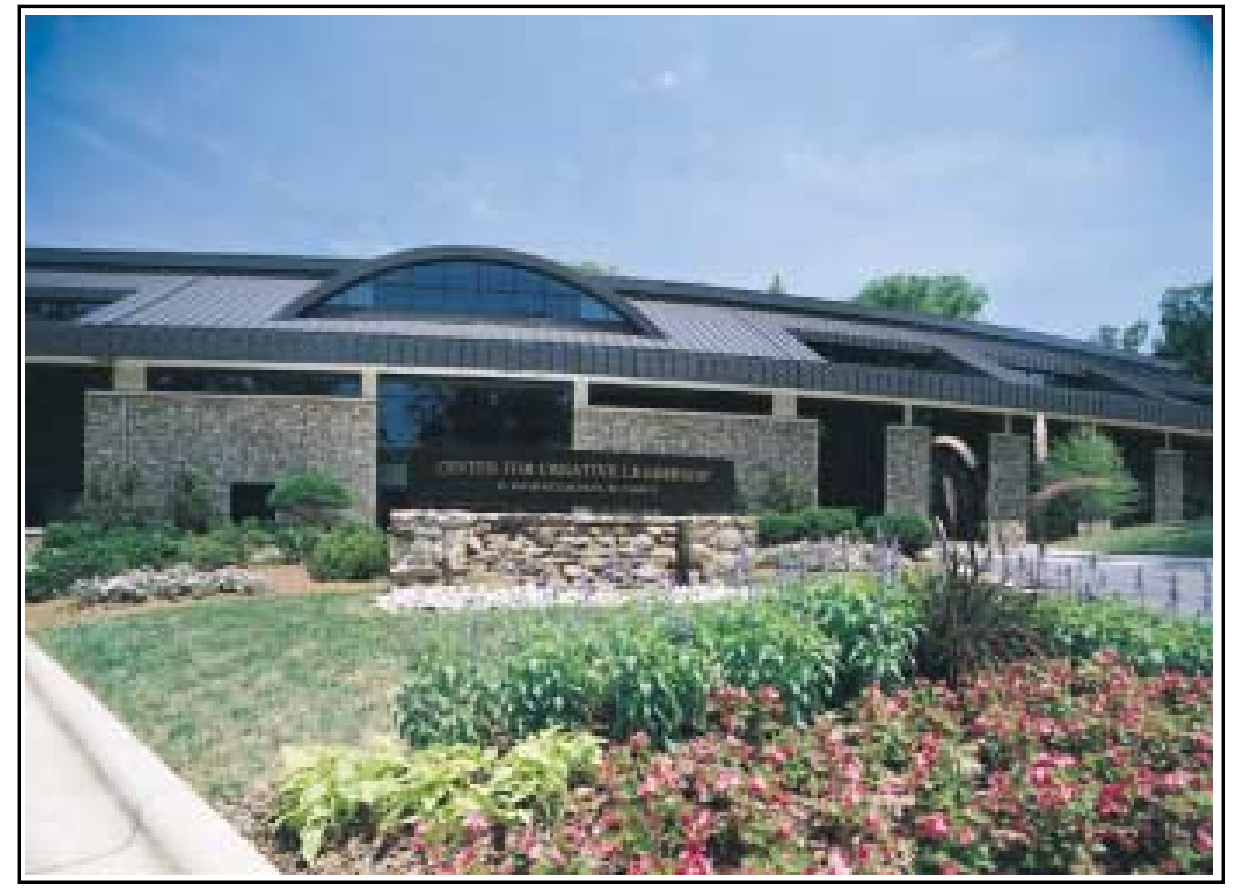

Exterior of the Center for Creative Leadership. collection with CCL staff. He was the first person at CCL to have a personal computer (an Apple) to organize information, the first to use a LAN, a local area network to link library computers together so that staff could update library databases from their own PCs, and the first person at CCL to develop an Intranet to share the library's staff-created databases with all CCL locations.

We now emphasize targeted services and, like many special libraries, are charged with proving our value to the organization. Through statistics, surveys, and collecting user feedback, we monitor our many proactive and responsive services. Our collection contains over 6,000 books, 140 periodicals, and the CCL archives. What we do not proactively acquire, we can usually get as needed. We also provide a virtual library through our Intranet that features 9 outside vendors (some full-text), approximately 22 databases created by library staff (of which about 13 are for CCL staff use), and approximately $62 \mathrm{Web}$ pages. From our virtual and traditional services, staff members learn that the library (now the Information Center) is the place to turn to if they need information. Information Center staff members tailor these resources and services to anticipate and provide the information needed to meet CCL's changing goals.

\section{Day to Day Life}

The Information Center has a lovely new location in the latest addition to the Greensboro campus. When we moved from the library to the Information Center in 1998, we gained a facility that is equipped with high-technology training and conference rooms and PC stations, and is wired for laptops to accommodate participants and visiting staff. The Information Center is well located in a central position on the second floor around the grand staircase above the lobby. Although the 
Information Center's primary mission is to serve the CCL, visitors may schedule appointments to use our materials in-house, and we try to refer them to helpful information if they call or write. While the location invites participants and visitors to see how central research is to the CCL's work, we are also experiencing the same changes other types of libraries may be noticing. We receive a number of our requests by phone or e-mail. E-mail and phone inquiries come from a range of people outside CCL - everyone from undergraduates to company vice-presidents - but mainly they are from CCL staff members.

The Information Center has a professional staff of four librarians, one paraprofessional, and a part-time library assistant. We serve over 500 staff enterprise-wide. In a special library, as in many other small libraries, each librarian wears many hats. Working in the context of a nonprofit with a dynamic mission also lends

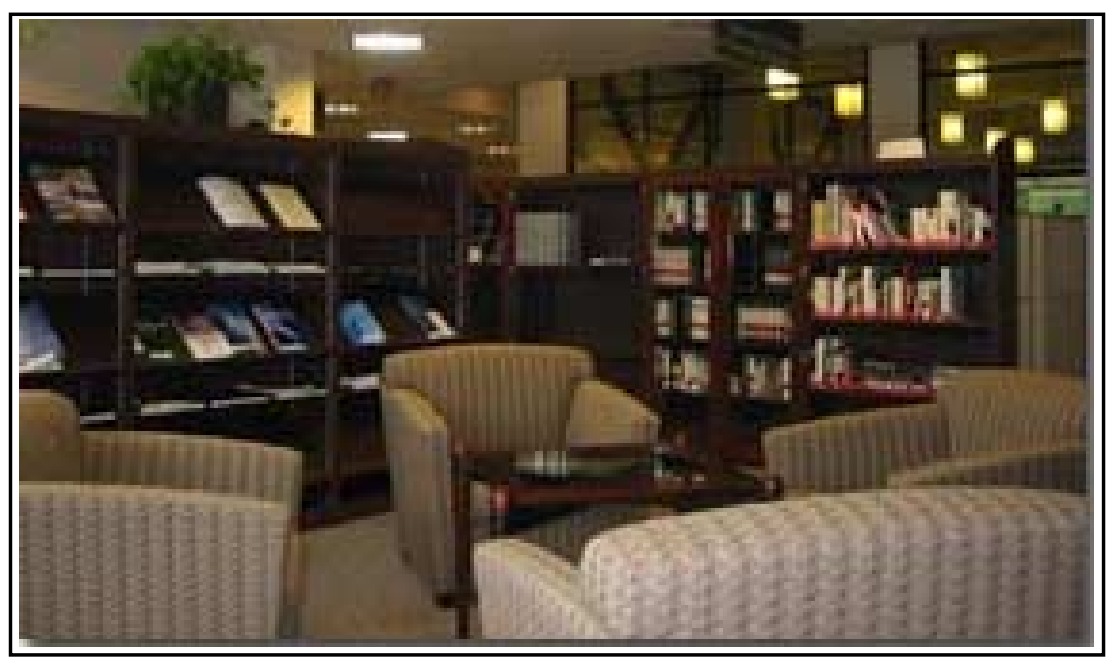
variety to our role at CCL-and to many concurrent projects. One day, we may be working on the usability of our virtual library databases. Another, we will be gathering information for a cutting-edge research project. Sometimes, the data needed does not yet exist, and that is useful information for our staff members as well. From my position on the CCL management team to each librarian's position in the CCL, we actively promote our role as information consultants to the organization. As a result, we are sometimes invited to serve on various committees or research projects from their nascence, which is our goal.

Other services, such as alerting services, can be offered with a personal touch that may not be possible in other types of libraries. Knowing which subjects people are interested in enables us to funnel information to them beyond the automatic alerts we also offer. Much time is spent on collection development, and there may be more collaboration with our clientele than one would find in other types of libraries. Having a specialized collection enables Information Center staff to develop in-depth content knowledge that puts us high on the learning curve of what's available in our subject area. The librarian can develop wonderful skills in quickly finding just the resources needed, although formats and vendors change. The librarian indexes and abstracts books, articles, videos, and exercises in leadership education for annotated bibliographies, online databases, and other projects. All of these services, plus behind-the-scenes projects that make our services possible, and on-demand projects such as literature searches, combine to give special librarians the depth of knowledge to provide the CCL with the information it needs to achieve its goals.

Information Center staff members also depend on a network of librarians in other libraries to supplement our services. The breadth of knowledge and willingness to help among the library community has been of tremendous help over the years. We thank you for it, and are always glad to return the favor!

Staff appreciation at the Center for Creative Leadership has been rewarding. I hope this aspect of day-to-day life is not limited to special librarians or to CCL. The first year we celebrated International Special Librarians' Day, the research staff surprised us with a party and brought refreshments, a banner, and its appreciation. More recently, we have been credited with helping the CCL to gain a $\$ 120,000$ grant for a new research project. The Information Center has undoubtedly contributed to CCL educational programs, products, and publications over the years in many ways, both acknowledged and not. Our goal is to continue 
collaborating on future programs, products, and services as an integral part of this educational institution's efforts.

\section{Current Publications}

If you would like to see some of the Center's current publications, visit www.ccl.org and go to the Bookstore. You will also find our research published in journals such as Harvard Business Review and Academy of Management Journal, and a variety of other venues. Listed here are a few short, practical guidebooks for the practitioner and in-depth analyses of our research written for the layperson.

Dalton, Maxine, Chris Ernst, Jennifer Deal, and Jean Leslie. Success for the New Global Manager: What You Need to Know about Working Across Distances, Countries, and Cultures. San Francisco: Jossey-Bass, 2002.

Hart, E. Wayne, and Karen K. Miller. Using Your Executive Coach: An Ideas Into Action Guidebook. Greensboro, NC: Center for Creative Leadership, 2001.

Livers, Ancella, and Keith Caver. Leading in Black and White: Working Across the Racial Divide in Corporate America. San Francisco: Jossey-Bass, 2002.

Martineau, Jennifer W., and Ellie Johnson. Preparing for Development: Making The Most of Formal Leadership Programs: An Ideas Into Action Guidebook. Greensboro, NC: Center for Creative Leadership, 2001.

Miller, Karen K., and E. Wayne Hart. Choosing an Executive Coach: An Ideas Into Action Guidebook. Greensboro, NC: Center for Creative Leadership, 2001.

Palus, Charles, and David Horth. The Leader's Edge: Six Creative Competencies for Navigating Complex Challenges. San Francisco: Jossey-Bass, 2002.

Pulley, Mary Lynn, Michael Wakefield, and Ellen Van Velsor. Building Resiliency: How to Thrive in Times of Change: An Ideas Into Action Guidebook. Greensboro, NC: Center for Creative Leadership, 2001.

Ruderman, Marian N., and Patricia J. Ohlott. Standing at the Crossroads: Next Steps for High-achieving Women. San Francisco: Jossey-Bass, 2002.

Sharpe, Davida, and Ellie Johnson. Managing Conflict with Your Boss: An Ideas Into Action Guidebook. Greensboro, NC: Center for Creative Leadership, 2002.

\section{References}

${ }^{1}$ Elin Christianson et al., Special Libraries: A Guide for Management, 3rd edition (Washington: Special Libraries Association, 1991), 1-2.

${ }^{2}$ Morgan W. McCall, Michael M. Lombardo, and Ann M. Morrison, The Lessons of Experience: How Successful Executives Develop on the Job (Lexington, MA: Lexington Books, 1988); Ann M. Morrison, Randall P. White, and Ellen Van Velsor, Breaking the Glass Ceiling: Can Women Reach the Top of America's Largest Corporations? (Reading, MA: Addison-Wesley, 1987, 1992); Ruderman, Marian N., and Patricia J. Ohlott, Standing at the Crossroads: Next Steps for High-achieving Women (San Francisco: Jossey-Bass, 2002).

${ }_{3}^{3}$ Cynthia D. McCauley, Russ S. Moxley, and Ellen Van Velsor, Editors, The Center for Creative Leadership Handbook of Leadership Development (San Francisco: Jossey-Bass; Greensboro, NC: Center for Creative Leadership). 